\title{
The Effectiveness of Endophytic Fungi Origin of Potato Plant Roots in Coffee Skin Compost Media to Suppress Development of Potato Leaf Disease (Phytophtora infestans)
}

\author{
Anna Fitriana ${ }^{1}$, Lukman Hakim², Marlina ${ }^{2}$ \\ ${ }^{1}$ Postgraduate Student of Agroecotechnology Education in Syiah Kuala University, Banda Aceh \\ ${ }^{2}$ Lecturer of Agroecotechnology Education in Syiah Kuala University, Banda Aceh \\ anna.martin180814@gmail.com
}

\begin{abstract}
Potato leaf blight is caused by Phytophthora infestans fungus is one of the important diseases in potato plants. The decrease in potato production due to P. infestans can reach $90 \%$. Until now, P. infestans pathogen attack is an important problem and there is no fungicide that is really effective against the disease. This study aims to examine the effectiveness of endophytic fungi from potato roots in suppressing the development of $P$. infestans potato leaf blight disease carried out at University Farm Stasiun Riset Bener Meriah (UFBM) Syiah Kuala University Tunyang Village, Timang Gajah District, Bener Meriah Regency from May to October 2014. The method used is the experimental method. The results of this study indicate that endophytic fungi from the roots of potato plants in coffee skin compost media can suppress the development of leaf blight caused by P. infestans, endophytic fungi from potato plant roots in coffee skin compost media. The best results were found in $B 9$ endophytic fungi isolates with the intensity of the pathogen attack P. infestans $48.00 \%$, the intensity of damage to potato plants due to pathogen P. infestans and $2.60 \%$, the weight of healthy tubers 332.4 grams.
\end{abstract}

Key words: endophytic fungi; potatoes; Phytophthora infestant

\section{Introduction}

Potato cultivation often gets disturbance from plant pest organisms (OPT) which causes losses and decreases in potato production. One of the diseases that often damage the potato crop is leaf blight caused by Phytophtora infestans fungus (Duriat et al., 2006). Potato leaf blight is very easy to develop in cold and humid areas $P$. infestant attacks leaves, stems, and tubers in the soil. Even though $P$. infestant is not a native pathogenic fungus, it is common to attack the organs of potato plants in the soil and above the ground (Djafaruddin, 2000)

Biological control is one of the environmentally friendly control techniques, the use of microorganisms as biological control agents can be applied to control leaf blight in potatoes. Endophytic fungi that have an attachment to its host have the opportunity to be used as biological control agents for leaf blight on potato plants. Endophytic fungi are usually found in a tissue such as leaves, twigs or roots of plants. This fungus can infect healthy plants in certain tissues and is able to produce mycotoxins, enzymes and antibiotics. The association of several endophytic fungi with host plants is able to protect their host plants from several virulent pathogens, both bacteria and fungi (Purwanto, 2008).

To utilize endophytic fungi as biological control agents, it is necessary to provide a growing and developing media for these endophytic fungi. Solid and liquid waste of coffee processing contains organic material which is quite high and very potential as a medium for growing microorganisms (Pandey et al., 2000). Coffee plant solid waste is a potential abundant local natural resource in Bener Meriah district.

Based on this description, it is necessary to conduct research on the effectiveness test of endophytic fungi from potato roots as biological agents for controlling leaf blight caused by $P$. infestans and are expected to be a better mutualistic symbiotic relationship. 


\section{Research Method}

The research was carried out at the University Farm of Bener Meriah Research Station (UFBM) at Syiah Kuala University located in Tunyang village, Timang Gajah District, Bener Meriah Regency in August to October 2014.

Testing the effect of endophytic fungi from the roots of potato plants in coffee compost media to suppress the development of pathogens was carried out in a paranet house with a length of 10 meters, width of 5 meters, and height of 2 meters. Using a non-factorial randomized block design (RBD) with 7 treatments and 5 replications. The composition of the treatment combination to be carried out can be seen in table 1 below:

Table 1. Arrangement of Combination of Treatment of Endophytic Fungi from Potato Plants in Coffee Skin Compost Media

\begin{tabular}{lll}
\hline No & Treatment & \multicolumn{1}{c}{ Remark } \\
\hline 1 & A & Control \\
2 & B & Coffee skin compost \\
3 & C & Fungus A8 \\
4 & D & FungusB9 \\
5 & E & Coffee skin compost + Fungus A8 \\
6 & F & Coffee skin compost + Fungus B9 \\
7 & G & Coffee skin compost + Fungus A8+ Fungus B9 \\
\hline
\end{tabular}

Coffee waste that comes from coffee plantations and is a red skin of coffee beans is collected and segmented so that it becomes compost. Coffee waste compost was applied to potato plant media at a dose of $50 \mathrm{gr} /$ plant.

Before planting a $15 \mathrm{~kg}$ polybag filled with soil, cow manure has been decomposed completely, then compost coffee skin and endophytic fungi according to the treatment. Potato seeds used in the form of K0 seed bulbs weighing about 30-45 grams per tuber.

Endophytic fungal colonies were suspended in sterile water at dilution 106 then applied to potato plants. Each individual plant was given $100 \mathrm{ml}$ of endophytic fungal suspension. The application of endophytic fungi was carried out 3 times, namely when planting, when the plants were 15 and 30 days after planting.

The variables observed in this study include:

a. the incidence of leaf blight due to P.infestans was done 7 days after inoculation (HSI). Disease incidence is calculated using the formula:

$$
\mathrm{K}=\frac{n}{N} \times 100 \%
$$

Where:

$\mathrm{K}=$ Occurrence of disease

$\mathrm{n}=$ Number of plants attacked

$\mathrm{N}=$ Number of plants observed

b. The intensity of Potato Plant Disease Due to Attack p.infestans 
Budapest International Research in Exact Sciences (BirEx) Journal

Volume 2, No 1, January 2020, Page: 101-105

e-ISSN: 2655-7827 (Online), p-ISSN: 2655-7835(Print)

www.bircu-journal.com/index.php/birex

emails: birex.journal@gmail.com

birex.journal.qa@gmail.com

Table 2. Value of Plant Damage Scale Due to P. Infestans Attack (Muzakir, 2015)

\begin{tabular}{cll}
\hline Score & \multicolumn{1}{c}{ Attack } & \multicolumn{1}{c}{ symptoms } \\
\hline & & $0 \%$ infected \\
0 & Healthy & $<25 \%$ infected to plant \\
1 & Light & $25-50 \%$ infected to plant \\
2 & Is & \\
3 & Weight & $50-75 \%$ infected to plant \\
4 & Very heavy & $>75 \%$ infected to plant
\end{tabular}

Observation of leaf blight severity due to $P$. infestans was carried out at 7 days after inoculation (HSI). The severity of the disease is calculated using the formula:

Where:

$\mathrm{I}=$ intensity of the disease

$\mathrm{n}=$ Number of plants that have the same scale damage category

$\mathrm{v}=$ Damage scale value for each attack category

$\mathrm{Z}=$ Highest damage scale value

$\mathrm{N}=$ Number of plants or plant parts observed

c. Healthy Tubers Weight

Healthy tuber weights were measured at harvest in each sample plant and averaged were expressed in grams. Measurement of healthy tuber weights is done by collecting healthy and weighed tubers.

d. Number of Healthy Bulbs

The number of healthy tubers was calculated at harvest of all sample plants and averaged was expressed in units of fruit. The calculation of healthy tubers is done by counting healthy tubers from sample plants.

\section{Results and Discussion}

\subsection{Disease incidence and disease intensity}

The results of the various analyzes showed that the treatment of endophytic fungi in coffee skin compost media significantly affected the incidence and disease intensity of potato plants. Data from observations of disease incidence and disease intensity can be seen in table 3.

Table 3. Disease incidence and disease intensity due to the influence of the application of endophytic fungi in coffee skin compost media

\begin{tabular}{|c|c|c|}
\hline Treatment & Disease event (\%) & $\begin{array}{l}\text { Intensity of } \\
\text { Disease (\%) }\end{array}$ \\
\hline A. Control & $100,00 \mathrm{~d}$ & 31.00 \\
\hline B. Coffee skin compost & $100,00 \mathrm{c}$ & 21.00 \\
\hline C. Fungus A8 & $96,00 \quad b$ & 15.00 \\
\hline D. Fungus B9 & $92,00 \quad b$ & 14.00 \\
\hline E. Coffee skin compost + Fungus A8 & 88,00 & 13.00 \\
\hline F. Coffee skin compost + Fungus B9 & 48,00 & 8.00 \\
\hline $\begin{array}{l}\text { G. Coffee skin compost + Fungus } \\
\text { A8 + Fungus B9 }\end{array}$ & $88,00 \quad b$ & 18.00 \\
\hline $\mathrm{BNJ}$ & 6,97 & 2,55 \\
\hline
\end{tabular}


Note: the number followed by the same letter in the same column is not significantly different based on the LSD test at the $5 \%$ level.

Table 3 shows that, the lowest disease incidence and disease intensity was found in the treatment of coffee waste compost + endophytic fungus B9 (F) $48.00 \%$ and $8.00 \%$ significantly different from the treatment (A, B, C, D, E and G). The low incidence of disease and the severity of potato diseases due to compost treatment of coffee waste + endophytic fungi $\mathrm{B} 9(\mathrm{~F})$.

Based on the results of the study of Pugliese et al., (2011) The level of compost's ability to suppress pathogens depends on the enrichment of compost with antagonistic agents, this study is proven by the fact that the compost power of $R$.solani in peanuts increases with T.harzianum antagonist agent. according to Prihatiningtias \& Wahyuningsih (2006) endophytic fungi are able to protect host plants from pathogens by producing secondary metabolites which are bioactive compounds that can function to kill pathogens.

\subsection{Number of healthy tubers and healthy tuber weights}

The results of the analysis of variance showed that the treatment of endophytic fungi in coffee skin compost media did not significantly affect the number of healthy tubers and healthy tuber weights of potato plants. Data from observations of the number of healthy tubers and healthy tuber weights can be seen in table 4 .

Table 4. Number of healthy tubers and healthy tuber weights due to the influence of the application of endophytic fungi in coffee skin compost media.

$\begin{array}{ccc}\text { Treatment } & \begin{array}{c}\text { Healthy tuber } \\ \text { counts }\end{array} & \begin{array}{c}\text { Healthy tuber weights } \\ \text { (gram) }\end{array}\end{array}$

\begin{tabular}{lll}
\hline A. Control & 26,20 & 315.4 \\
B. Coffee skin compost & 33,20 & 233.2 \\
C. FungusA8 & 31,80 & 283.0 \\
D. Fungus B9 & 25,20 & 208.0 \\
E. Coffee skin compost + Fungus A8 & 33,20 & 329.2 \\
F. Coffee skin compost + Fungus B9 & 35,60 & 332.4 \\
G. Coffee skin compost + Fungus & 27,00 & 181.6 \\
A8 + Fungus B9 & & \\
\hline
\end{tabular}

\section{BNJ}

Note: the number followed by the same letter in the same column is not significantly different based on the LSD test at the $5 \%$ level

Table 4 shows that, the highest number of healthy tubers was found in the compost treatment of coffee waste + B9 (F) endophytic fungi, but not significantly different between treatments. The highest prevalence of healthy tuber weight was found in the compost treatment of coffee skin + fungus B9 (F) but not significantly different between treatments.

Sudantha \& Abadi (2006) states that the presence of endophytic fungi in plant tissues is very beneficial for the plant itself by increasing plant tolerance to heavy metals, increasing drought resistance, suppressing pest attacks, and systemic resistance to pathogens. Istifadah et al., (2008) states that the addition of endophytic fungi into compost can have the potential to reduce the severity of disease, in addition to providing nutrients for compost fertilizer plants can also carry antagonistic organisms. 
Budapest International Research in Exact Sciences (BirEx) Journal

Volume 2, No 1, January 2020, Page: 101-105

e-ISSN: 2655-7827 (Online), p-ISSN: 2655-7835(Print)

www.bircu-journal.com/index.php/birex

emails: birex.journal@gmail.com

birex.journal.qa@gmail.com

\section{Result}

Endophytic fungi from the roots of potato plants in coffee skin compost media can suppress the development of leaf blight caused by $P$. infestans the best results are found in isolates of endophytic $B 9$ fungi in coffee skin compost media based on observations of $48.00 \%$ disease incidence and disease intensity $8.00 \%$.

\section{References}

Djafarudin. 2000. Dasar-dasar pengendalian penyakit tanaman. Bumi Aksara. Jakarta.

Duriat AS, Gunawan OS, \& Gunaini N. 2006. Penerapan teknologi PHT pada tanaman kentang. monograf No. 28. Balitsa.59.

Lologau BA. 2006. Tingkat serangan lalat pengorok daun, Liriomyza huidobrensis (Blanchard) dan kehilangan hasil pada tanaman kentang. Balai Pengkajian Teknologi Pertanian Sulawesi Selatan.

Muzakir. 2015. Penambahan Trichoderma pada kompos limbah kakao dan pengaruhnya dalam menekan patogen tular tanah Phytophtora palmivora pada pembibitan kakao. Thesis, Unsyiah.

Pandey A, Soccol CR, Nigam P, Brand D, Mohan R \& Roussos S. 2000. Biotechnological potential of coffee pulp and coffee husk for bioprocesses. Biochemical Engineering Journal, 6, 153-162.

Prihatiningtias W \& Wahyuningsih MSH. 2006. Prospek mikroba endofit sebagai sumber senyawa bioaktif. Fakultas Farmasi UGM, Yogyakarta. Fakultas Kedokteran UGM, Yogyakarta

Pugliese M, Liu BP, Gullino ML \& Garibaldi A. 2011. Microbial enrichment of compost with biological control agents to enhance suppressiveness to four soil-borne diseases in greenhouse. J.of plant Diseases and protection, 118: 45-50

Purwanto R. 2008. Peranan mikroorganisme endofit sebagai penghasil antibiotik. www.kabarindonesia.com. Accessed $01^{\text {st }}$ february 2014

Sudantha IM \& Abadi AL. 2006. Uji efektivitas beberapa isolat jamur endofit antagonistik dalam meningkatkan ketahanan induksi beberapa klon vanili terhadap penyakit busuk batang. Universitas Mataram. Mataram.

Toding ET, Meity SS, Widodo \& Maggy TS. 2012 Potensi cendawan endofit sebagai agens pengendali hayati Phytophthora palmivora (Butl.) Butl. Penyebab Busuk Buah Kakaoj. Agron. Indonesia 40 (2): 146 - 152 